\begin{tabular}{lllll} 
ZAPISKI HISTORYCZNE & $-\underset{\text { TOM }}{\text { Zeszyt } 3}$ \\
\hline
\end{tabular}

http://dx.doi.org/10.15762/ZH.2014.02

TOMAS ČELKIS (Wilno)

\title{
STAN DRÓG LĄDOWYCH I STRUKTURA SYSTEMU POŁĄCZEŃ W WIELKIM KSIĘSTWIE LITEWSKIM W KOŃCU XV-XVII WIEKU
}

Słowa kluczowe: sieć drożna, geografia historyczna, wczesnonowożytna Litwa, komunikacja lądowa

\section{WSTEP}

W ramach geografii historycznej badane są: osadnictwo, pojęcie granic państwa (zewnętrznych i wewnętrznych) i rozwój systemu dróg. Problem rozwoju dróg europejskich doczekał się już pewnego zainteresowania ze strony naukowców ${ }^{1}$. Są one analizowane jako środek komunikacji mieszkańców na określonym terytorium ukazujący dynamikę mobilności. W procesie tworzenia się struktury państwa duże nasycenie jego terytorium drogami uważane jest za wyraz skutecznego zarządzania nim, szczególnie uwzględniając fakt, że monarcha rządząc państwem, odbywał wiele podróży.

Szlaki komunikacyjne można podzielić na wodne i lądowe. Wyróżniamy różne rodzaje dróg: wśród dróg wodnych rzeczne i morskie, a spośród lądowych - górskie i równinne. Warto zwrócić uwagę na odmienny sposób tworzenia się lądowych i wodnych szlaków komunikacyjnych. Koryta rzek oraz inne zbiorniki wodne są obiektami geograficznymi ukształtowanymi w sposób naturalny, które dostosowywano do potrzeb komunikacyjnych i handlowych, czasami je doskonalono - urządzano porty lub przystanie. Tymczasem drogi lądowe powstawały w wyniku intensywnej działalności ludzkiej wynikającej z potrzeb ekonomicznych i społecznych. Drogi można też podzielić w zależności od pełnionych funkcji na: handlowe, wojenne itd.

W artykule zajmuję się drogami lądowymi w Wielkim Księstwie Litewskim (dalej cyt. WKL) w okresie od końca XV do końca XVII w., uwagę swą skupiając na ich strukturze tworzącej złożony system komunikacji na terytorium państwa litewskiego. Badania nad drogami dają możliwość poznania mobilności mieszkańców oraz ustalenia roli traktów komunikacyjnych w funkcjonowaniu państwa.

\footnotetext{
${ }^{1}$ Maxwell G. LAY, Ways of the World. A History of the World's Roads and of the Vehicles That Used Them, New Brunswick (New Jersey) 1992; Georges LiveT, Histoire des routes et des transports en Europe. Des chemins de Saint-Jacques à l'âge d’or des diligences, Strasbourg 2003.
} 
W historiografii litewskiej problemem połączeń drogowych zainteresował się w okresie międzywojennym Zenonas Ivinskis, który prowadząc badania nad handlem Litwy z Prusami do końca XVI w., omówił układ dróg wodnych i lądowych w ówczesnym WKL ${ }^{2}$. Potem przez dłuższy czas tematyka ta nie cieszyła się zainteresowaniem naukowców, powrócono do niej dopiero w okresie sowieckim. Wówczas Albinas Gulbinskas przygotował szereg publikacji o charakterze popularnonaukowym, w których kwestię komunikacji i szlaków handlowych w WKL omówił w bardzo ogólny sposób ${ }^{3}$. W 1978 r. Vytautas Puodžiukynas napisał pracę dyplomową na Uniwersytecie Wileńskim na temat dróg na Litwie w wiekach XVI-XIX ${ }^{4}$. Rozprawa ta była jednak oparta niemal wyłącznie na wcześniejszej historiografii. W nieco większym stopniu na źródłach oparł swój artykuł Povilas Vitkevičius ${ }^{5}$, który zajął się funkcjonowaniem poczty na Litwie w wiekach XIII-XIX. Z kolei w 1994 r. Jūratė Kiaupienè napisała artykuł o czterech księgach ceł Kowna i Jurborka $\mathrm{z}$ lat 1600-1613, opisując także wymienione w tych źródłach drogi ${ }^{6}$. Również w artykule Vincasa Žilènasa na temat handlu w Wilnie w wiekach XVI-XVII omówiono niektóre drogi lądowe i wodne, którymi kupcy przybywali do Wilna ${ }^{7}$.

Inni badacze również zwrócili uwagę na stan dróg WKL. W rozprawie doktorskiej Rūstisa Kamuntavičiusa poświęconej obrazowi Litwy w piśmiennictwie francuskim i włoskim w kilku rozdziałach przedstawiono analizę systemu litewskich dróg, a także przytoczono zdanie współczesnych obcokrajowców na temat warunków podróżowania w WKL ${ }^{8}$. Codzienne warunki podróży w WKL w XVI w. omówiła też Raimonda Ragauskienė, dokonując przeglądu stanu dróg i usług świad-

${ }^{2}$ Zenonas Ivinskis, Lietuvos prekyba su prūsais. Pirma dalis. Iki XVI amžiaus pradžios, Kaunas 1934, s. 114-125.

${ }^{3}$ Albinas GulbinsKas, Sauskeliu tinklas Lietuvoje iki 1940 m., Lietuvos TSR Mokslų akademijos darbai, A serija, t. 3 (25): 1963, s. 15-28; idem, Lietuvos transporto tinklu formavimosi raida iki 1940, Geografinis metraštis, Nr. 9 (Lietuvos TSR gyventojai ir darbo jègos ištekliai), Vilnius 1971, s. 131-153; idem, Формирование и совершенствование транспортной системы Литовской CСР, Вильнюс 1977, с. 9-31; idem, Vytautas Puronas, Vytautas Ragevičıus, Stefanija Jurginienė, Virginija TAMošaitienĖ, Transporto raida Lietuvoje, Vilnius 1983.

${ }^{4}$ Vytautas Puodžıukynas, „Lietuvos senieji keliai XVI-XIX a. pirmoje pusèje (iki $1861 \mathrm{~m}$.)”, Vilnius 1978 (maszynopis w: Vilniaus universiteto biblioteka, Rankraščių skyrius (dalej cyt. VUB, RS), sygn. F85-1237).

${ }^{5}$ Повилас П. Виткявичюс, Старинная почта в Прибалтике, [in:] Из истории естествознания и техники Прибалтики (научно-технические идеи в Прибалтике), Вильнюс 1980, s. $65-77$.

${ }^{6}$ Jūratė KiAupIenĖ, Nemuno prekybos keliu i Baltijos jūros uostus XVII a. Klaipédos miesto ir regiono archeologijos ir istorijos problemos, Acta Historica Universitatis Klaipedensis, [t.] 2: 1994, s. $40-43$.

${ }^{7}$ Vincas ŽILĖNas, Vilniaus miesto prekybos bruožai XVI ir XVII šimtmetyje, Mūsų praeitis, t. 4: 1994 [druk: 1995], s. 90-130.

${ }^{8}$ Rūstis KamuntavičıUs, „Lietuvos ịvaizdžio stereotipai italų ir prancūzų XVI-XVII a. literatūroje”, Kaunas 2002 (Vytauto Didžiojo Universitetas, Humanitariniai mokslai. Istorija $(05 \mathrm{H})$; maszynopis w: Lietuvos Nacionalinè Martyno Mažvydo biblioteka, Rankraščių skyrius (dalej cyt. LNMB, RS), sygn. F132-2133), s. 33-41. 
czonych przez domy noclegowe 9 . W dysertacji Deimantasa Karvelisa poświęconej księstwu birżańskiemu dokonano analizy dróg i sieci karczm przydrożnych oraz ich rozwoju ${ }^{10}$. Historyk Laimontas Karalius w swoich badaniach zajmował się z kolei wyłącznie stanem dróg w WKL oraz kwestiami celnymi ukazującymi charakterystyczne cechy podróży $y^{11}$. Należy dodać, że na podobny temat w odniesieniu do wieków XIII-XV pisał też autor tego artykułu ${ }^{12}$.

Ważny w tej tematyce jest dorobek naukowców z sąsiednich krajów. W książce łotewskiego historyka Vilnisa Pāvulānsa opisującej sieć dróg w wiekach XIII-XVII znajdujących się na terytorium należącym obecnie do Łotwy poruszono też kwestię struktury komunikacyjnej na ziemiach $\mathrm{WKL}^{13}$. Należy również wspomnieć o publikacjach historyków niemieckich: Friedricha Brunsa i Hugo Weczerki, w których przedstawili historię hanzeatyckich szlaków handlowych, a właściwie - szerzej - traktów komunikacyjnych funkcjonujących w regionie Bałtyku ${ }^{14}$. W ich wspólnej monografii przytoczono ważne materiały na temat układu dróg w WKL. Sporo przykładów zajmowania się tą tematyką mamy w historiografii białoruskiej. Na ten temat pisali: Zinovij Kopysskij ${ }^{15}$, Vadim Żuczkiewicz ${ }^{16}$, Armen Sardarov ${ }^{17}$, Wasilij

${ }^{9}$ Raimonda RagauskienĖ, „Dingę istorijoje”: XVI a. LDK privačiu archyvu dokumentų dinami$k a$, [in:] Istorijos šaltinių tyrimai, t. 3, sudarẻ Darius AnTANAvičius, Vilnius 2010, s. 94-104.

${ }^{10}$ Deimantas Karvelis, „Radvilų Biržų kunigaikštystès visuomenè ir jos komunikacija 1589-1655 m.", Kaunas 2009 (Vytauto Didžiojo Universitetas, Humanitariniai mokslai. Istorija (05 H); maszynopis w: LNMB, RS, syg. F132-478), s. 60-66, 356-364.

${ }^{11}$ Laimontas Karalıus, Tiltai, pervažiuojamieji perkolai, kamšos, pagrandos, mediniai grindiniai, pylimai Lietuvos Didžiosios kunigaikštystès sausumos keliuose XVI amžiuje, Lietuvos istorijos metraštis, [t.] 1: 2008, Vilnius 2009, s. 5-25; idem, „Privačiu muitų sudètis ir teisinè sudètis Lietuvos Didžiojoje Kunigaikštystėje (XV a. II pusè - 1566 m.)", Vilnius 1998 (praca magisterska napisana na Wydziale Historii Uniwersytetu Wileńskiego, przechowywana w Katedrze Teorii Historii i Historii Kultury); idem, Privatūs muitai XVI a. Lietuvos Didžiosios Kunigaikštystèje: dar viena bajorų ekonominio aktyvumo sritis?, [in:] Tarp istorijos ir būtovés: studijos prof. Edvardo Gudavičiaus 70-mečiui, sudare Alfredas Bumblauskas, Rimvydas Petrauskas, Vilnius 1999, s. 263-276; idem, Upiu keltu rinkliavos Lietuvos Didžiosios Kunigaikštystès muitu sistemoje XVI a. I pusèje, Mūsų praeitis, t. 6: 1999, s. 3-22.

${ }^{12}$ Tomas ČELKIs, Keliais po viduramžiu Lietuvą. I: XIII-XV amžiaus pirmosios puses sausumos keliu samprata, Lituanistica, T. 59: 2013, Nr. 2 (92), s. 61-76; idem, Keliais po viduramžiu Lietuvą. II: XIII-XV amžiaus pradžios karo žygiu sąlygos, ibid., T. 59: 2013, Nr. 3 (93), s. 125-137.

${ }^{13}$ Vilnis Pāvulāns, Satiksmes celi Latvijā XIII-XVII gs., Rīgā 1971; idem, Hauptverkehrswege und Richtungen der Kulturverbindungen in Lettland vom 10. bis zum 17. Jahrhundert, [in:] Colloquium Balticum ethnographicum. Wege und Teilnehmer ethnisch-kultureller Kontakte in der Ostseeregion, hrsg. v. Saulvedis Cimermanis, Rīgā 1993, s. 10-15.

${ }^{14}$ Hansische Handelsstrassen, [Tl. 2]: Textband, auf Grund von Vorarbeiten v. Friedrich Bruns bearb. v. Hugo Weczerka (Quellen und Darstellungen zur hansischen Geschichte, Bd. 13/2), Weimar 1967; Friedrich Bruns, Hansische Handelsstrassen. Atlas, bearb. v. Hugo WeCzerKa (Quellen und Darstellungen zur hansischen Geschichte, Bd. 13/1), Köln 1962.

${ }^{15}$ Зиновий Ю. Копысский, Экономическое развитие городов Белоруссии в XVI - первой половине XVII в., Минск 1966, s. 152-155.

${ }^{16}$ Вадим А. Жучкевич, Дороги и водные пути Белоруссии, Минск 1977.

${ }_{17}$ Армен С. Сардаров, История и архитектура дорог Белоруссии, Минск 1978; idem, Путетворение: история и культура белорусских дорог, Минск 2009. 
Meleszko $^{18}$. Autorzy ci jednak nie wychodzili w swoich badaniach poza ustalenia wcześniejszej historiografii. Artykuł o drogach na terytorium Białorusi w XVI-XVII w., napisany na podstawie badań archiwalnych, opublikował Aleś Daunar ${ }^{19}$. Z kolei rosyjski uczony Siergiej Gołubcow omówił drogi handlowe biegnące do Nowogrodu w XVI-XVII w., wymieniając m.in. trakty z Połocka i Smoleńska ${ }^{20}$. Wreszcie ukraiński historyk Volodimir Priszliak opisał „Trakt Witolda” na Wołyniu, wzmiankowany w źródłach pochodzących z XVI-XVII w. ${ }^{21}$

W historiografii polskiej badania nad połączeniami drogowymi zaczęto prowadzić stosunkowo szybko. W okresie międzywojennym Seweryn Wysłouch wydał książkę o posługach komunikacyjnych w miastach WKL na prawie magdeburskim, w której skupił uwagę na prawnych aspektach nadzoru nad drogami, warunkach udzielania noclegów na stacjach pocztowych oraz na kwestii wydawania podwód ${ }^{22}$. W kolejnym roku ukazało się jego studium o systemie dawnych dróg Polesia w XVI-XVIII w. ${ }^{23} \mathrm{~W}$ swoich badaniach w największym stopniu oparł się na źródłach siedemnastowiecznych, wykorzystując je retrospektywnie, ale system komunikacji we wcześniejszym okresie omówił dość pobieżnie. W tej tematyce istotny wkład do historiografii wniosła Alina Wawrzyńczyk ${ }^{24}$, która w swojej monografii ustaliła i opisała szlaki handlowe WKL i Polski prowadzące do państwa moskiewskiego. $\mathrm{Z}$ uwagi na podejmowany przeze mnie $\mathrm{w}$ tym artykule problem dróg prowadzących do Wilna i ich położenia należy wymienić także artykuł Józefa Maroszka dotyczący ulic Wilna w XIV-XVIII w. ${ }^{25}$

Biorąc pod uwagę dotychczasowe ustalenia historiografii, można stwierdzić, że badania nad systemem dróg lądowych w WKL znajdują się wciąż w fazie początkowej. Dotychczas skupiano się bardziej na kształtowaniu się poszczególnych traktów oraz określeniu przyczyn lokalizacji dróg, wskazując przede wszystkim

\footnotetext{
${ }^{18}$ Василий И. Мелешко, Могилев в XVI - середине XVII в., Минск 1988, s. 96-119.

${ }^{19}$ Алесь Доўнар, „Масты у паутара пруты”. Нарыс з гісторыі дарожных камунікащыяу Беларусі XVI-XVIII cтст., Спадчына, 2003, № 2-3 (152), s. 63-69.

${ }^{20}$ Иван А. Голубцов, Пути сообщения в бывщих землях Новгорода Великого в XVI-XVII веках и их отражение на русской карте середины XVII века, Вопросы географии, сб. 20, Москва 1950, s. 271-302.

${ }^{21}$ Володимир Пришляк, Старий „гостинєи Витолтов” (Вітовтова дорога XIV-XVII cm.), [in:] Минуле і сучасне Волині та Полісся. Сереховичі та Старовижівщина історії України, Волині та Полісся. Науковий збірник, випуск 21: Матеріали ХХІ Волинської обласної науковопрактичної історико-краєзнавчої конферениії, присвяченої 15-й річниці Незалежності України та 505-річчю першої писемної згадки про с. Сереховичі, 17 листопада 2006 р., Луцьк 2006, s. 21-23.

${ }^{22}$ Seweryn WysŁouch, Postugi komunikacyjne w miastach W. Ks. Litewskiego na prawie magdeburskiem do połowy XVI w., Wilno 1936.

${ }^{23}$ Idem, Dawne drogi Polesia. Ze studiów nad historia gospodarcza Polesia XVI-XVIII w., Ateneum Wileńskie, R. 12: 1937, s. 146-204.

${ }^{24}$ Alina Wawrzyńczyк, Studia $z$ dziejów handlu Polski z Wielkim Księstwem Litewskim i Rosja w XVI wieku, Warszawa 1956, s. 26-40.

${ }^{25}$ Józef Maroszek, Ulice Wilna w XIV-XVIII wieku, Kwartalnik Historii Kultury Materialnej, R. 47: 1999, nr 1-2, s. 163-186.
} 
na czynniki ekonomiczne. W badaniach tych droga była rozumiana jako środek rozwoju gospodarczego. A przecież drogi nie służyły tylko do transportu towarów, były ważne także z innych względów. Chociażby zaspokajały potrzebę komunikacji lokalnej między mieszkańcami, wynikającą $\mathrm{z}$ ich wzajemnych więzi ${ }^{26}$. Sieć dróg była też istotna dla terytorialnej struktury państwa, ponieważ dobra komunikacja wpływała na sprawność administracji.

Układ traktów lądowych zależał od rozwoju poszczególnych miejscowości. Przyjmuje się, że część systemu komunikacyjnego stanowiły drogi stałe, inne zaś powstawały lub zanikały w zależności od zaludnienia kraju ${ }^{27}$. Następowało to w wyniku zmian w strukturze administracji wewnętrznej państwa. Z tego punktu widzenia istotnym czynnikiem zmian w sieci dróg były kierunki wewnętrznej kolonizacji i procesów osadniczych. W trakcie badań nad oznaczeniami granic posiadłości prywatnych w WKL w XV-XVI w. zauważono, że ziemia była ciągle przywłaszczana, zajmowano nowe tereny, powstawały nowe wsie, dwory i miasteczka ${ }^{28}$. W zależności od tego zmieniała się sieć połączeń.

Pierwszym aspektem, którym chciałbym się zająć w artykule, jest problem definicji pojęcia „droga” w źródłach. Analiza wyjaśni, dlaczego trakty lądowe w dokumentach określano różnymi nazwami. Drugie zagadnienie dotyczy problemu stanu dróg lądowych w WKL, o czym pisał L. Karalius ${ }^{29}$. Jest to istotne, gdyż nowe dane archiwalne i informacje zawarte w opublikowanych źródłach zachęcają do podjęcia na nowo tej kwestii. Trzecim zadaniem będzie spojrzenie na litewskie drogi jako zorganizowany system połączeń komunikacyjnych i traktów handlowych. Przyjrzenie się wszystkim tym zagadnieniom znacznie przekraczałoby objętość jednego artykułu, dlatego do bardziej szczegółowych badań wybrałem Wilno - centrum polityczne i gospodarcze WKL, które było ważnym ośrodkiem komunikacji lokalnej i ponadregionalnej. W wypadku tego miasta można stworzyć model systemu dróg głównych i lokalnych, które były z nim połączone, a na tej podstawie pokusić się o szersze wnioski dotyczące struktury połączeń komunikacyjnych w WKL.

Ramy chronologiczne pracy są uwarunkowane rozwojem struktury terytorialnej WKL. W końcu XV w. zostały ukształtowane granice WKL, co w pewnym tylko

\footnotetext{
${ }^{26}$ Np. na temat zawodowych podróży rzemieślników zob. Фёдор И. Леонтович, Сельские промышленники въ Литовско-Русскомъ государстве, Варшавские университетские известия, кн. 4, Варшава 1897, s. 1-24; кн. 5, Варшава 1897, s. 25-57; кн. 2, Варшава 1898, s. 1-40; кн. 3, Варшава 1898, s. 41-68; Русская историческая библиотека (dalej суt. РИБ), т. 30: Литовская Метрика. Книга публичныхъ делъ, Юрьевъ 1914, № 7, s. 614-615.

${ }^{27}$ Sieć dróg w WKL XIV - pierwszej połowy XV w. pod względem skali różniła się od dróg późniejszych, zob. T. ČelKIs, Keliais po viduramžių Lietuvą. I, s. 61-76.

${ }^{28}$ Zob. idem, Privačios žemèvaldos ribu nustatymas ir žymejimas XV-XVI a. Lietuvos Didžiojoje Kunigaikštystejje, [in:] Istorijos šaltiniu tyrimai, t. 3, sudare Darius Antanavičıus, Vilnius 2011, s. 31-58; Juozas Jurginis, Baudžiavos įsigalejjimas Lietuvoje, Vilnius 1962, s. 112-123; Stanisław AleXANDrowicz, Geneza i rozwój sieci miasteczek Białorusi i Litwy do połowy XVII wieku, [in:] idem, Studia z dziejów miasteczek Wielkiego Księstwa Litewskiego, Toruń 2011, s. 19-93.

${ }^{29}$ L. Karalius, Tiltai, s. 5-25.
} 
stopniu dotyczyło granic zewnętrznych, ale przede wszystkim objęło wewnętrzne granice administracyjne ${ }^{30}$. Kształtowały się centra miejscowości, od których zależał układ dróg lądowych. Badania Stanisława Alexandrowicza pokazują, że od XV do połowy XVII w. w WKL intensywnie rozwijała się sieć miasteczek ${ }^{31}$, co oznacza, że jednocześnie kształtował się układ dróg. Dlatego cezurą końcową badań może być koniec XVII w. Należy jednak dodać, że brakuje kompleksowych źródeł dotyczących badanego okresu, tzn. wieków XV-XVII. Z tego powodu w nieunikniony sposób poszerza się granica chronologiczna w poszukiwaniu źródeł. Retrospektywnie wykorzystywane są także znacznie liczniejsze w porównaniu z wcześniejszym okresem źródła osiemnastowieczne. Jednak należy koniecznie zaznaczyć, że na źródła z tego stulecia powoływano się jedynie w przypadkach wyjątkowych, nie były one wykorzystane kompleksowo.

Badania oparte zostały na źródłach archiwalnych oraz materiałach opublikowanych. Dokumenty archiwalne to najczęściej źródła o charakterze ikonograficznym: plany dróg z XVII-XVIII w. lub rysunki inżynieryjne, które prezentują urządzenia mające usprawnić połączenia drogowe ${ }^{32}$. Źródła publikowane to głównie wydane drukiem księgi Metryki Litewskiej oraz inwentarze dworów i miejscowości, w których znajdują się informacje o drogach. Warto zwrócić uwagę, że w inwentarzach podawane są nazwy ulic miasteczek i miast, które wskazywały kierunek drogi (np. ul. Wileńska) prowadzącej do innego miasta.

\section{DEFINICJE „DROGI” W ŹRÓDŁACH \\ OD DRUGIEJ POŁOWY XV DO XVII W.}

Historycy różnie tłumaczą definicje zawarte w dostępnych różnojęzycznych źródłach, odwołując się często do współczesnego rozumienia słowa „droga”, dzieląc ówczesne litewskie trakty na dwie podstawowe grupy: drogi większe i mniejsze $^{33}$. Jednak bardziej dogłębne przyjrzenie się zróżnicowanej terminologii w odniesieniu do tej kwestii pozwala lepiej zrozumieć różnice występujące między poszczególnymi rodzajami dróg i tym samym lepiej poznać ówczesną strukturę dróg lądowych.

Większa część źródeł z końca XV do XVII w. wykorzystanych do tych badań została spisana w językach ruskim i polskim, mniejsza - po łacinie. Małe drogi w miejscowościach, a nawet ścieżki w dokumentach są nazywane „дорожка” lub

${ }^{30}$ Zob. Jūrate KiaupienĖ, Rimvydas Petrauskas, Lietuvos istorija, t. 4: Nauji horizontai: dinastija, visuomenè, valstybé, Vilnius 2009, s. 220-298; Jūratė KIAUPIENĖ, Ingė LuKšAité, Lietuvos istorija, t. 5: Veržli naujujų laiku pradžia. Lietuvos Didžioji Kunigaikštystė 1529-1588 metais, Vilnius 2013, s. 133-185.

${ }^{31}$ S. Alexandrowicz, Geneza, s. 19-93.

${ }^{32}$ Latvijas Valsts vēstures archīvs, Rīga (dalej cyt. LVVA); Lietuvos valstybės istorijos archyvas, Vilnius (dalej cyt. LVIA).

${ }^{33}$ Zob. S. WysŁouch, Dawne drogi, s. 146; Deimantas Karvelis, Laiškas kaip komunikacijos priemonè Radvilu Biržų kunigaikštystèje XVI a. pabaigoje - XVII a. pirmoje puseje, Lituanistika, 1999, Nr. 1 (37), s. 12. 
„стешка”: „дорожка которая идет от дворца пана Александрова” (1515 r.) ${ }^{34}$; „до стешки, которую ходетъ отъ Ромашковъ до Чижелевъ” (1589 r.) ${ }^{35}$. Większe drogi są nazwane „дорога”: „подле дороги, которая идеть от Смолина до Збирогов” (1566 r. $)^{36}$. W języku polskim także używano podobnego pojęcia „droga”: „droga ku Prutcom” (1506 r.) ${ }^{37}$; „drogi, z Nurca ku Żyrczycom” (1638 r.) ${ }^{38}$. Odpowiednikami tych pojęć w języku łacińskim są kolejno: „via” („ad alium locum Grussen dictum, ubi ad viam est situm saxum”, $1545 \mathrm{r}^{39}$ ), lub „tractus” („tractu Obelensi duxerunt” $\left.{ }^{\prime 0}\right)$. Ten ostatni termin przeszedł do języka polskiego: „w trakcie Kobrynskim” (1685 r. $)^{41}$. Terminy te stosowano do ogólnego określenia małych i dużych dróg łączących miejscowości, lecz czasami zastępowano je specjalnym terminem podkreślającym znaczenie traktu: „droga wielka” (główna) lub „gościniec".

W źródłach spisanych w języku ruskim drogi wielkie (gościńce) oraz drogi pospolite często określano mianem „гостинца”: „отъ дороги великое, гостинца, который идетъ съ Каменца до Шершева” (1599r.) ${ }^{42}$; „гостинцомъ, который идетъ зъ розныхъ краевъ” (1613 r. $)^{43}$. Pojęcie o podobnej semantyce było szeroko używane w języku polskim: „podlie goscienca Wilenskiego, nad wypustem miasta Narewskiego" (1560 r.) ${ }^{44}$. Wymienione nazwy mogły dotyczyć zarówno drogi „wielkiej”, jak i „wolnej” (tymi słowami nazywano drogi główne, czyli goś-

${ }^{34}$ Lietuvos Metrika. Knyga Nr. 9 (1511-1518). Užrašymų knyga 9, parengè Krzysztof PiETкIEwICz, Vilnius 2003, nr 463, s. 269; Гістарьчны слоўнік беларускай мовы (dalej суt. ГСБМ), Выпуск 32, Мінск 2012, s. 374-375.

${ }_{35}$ Акты, издаваемые Виленскою археографическою комиссиею (dalej суt. AВАК), т. 14: Инвентари имений XVI-го столетия, Вильна 1888, № 37, s. 351. Analogiczne pojęcia funkcjonują w języku polskim, zob. Słownik staropolski, t. 9, Wrocław-Warszawa-Kraków-Gdańsk-Łódź 1982-1987, s. 6-7.

${ }^{36}$ Lietuvos Metrika. Knyga Nr. 51 (1566-1574). Užrašymų knyga 51, parengè Algirdas BaLIULIS, Raimonda Ragauskiené, Aivas Ragauskas, Vilnius 2009, nr 1, s. 27; ГСБМ, Выпуск 8, Мінск 1987, s. 308.

${ }^{37}$ АВАК, т. 7: Акты Городненского гродского суда, Вильна 1874, № 4, s. 65.

${ }^{38}$ Ibid., т. 12: Акты главного литовского трибунала, Вильна 1883, № 106, s. 449; Słownik staropolski, t. 2, Wrocław-Kraków-Warszawa 1956-1959, s. 183-186.

${ }^{39}$ Tomas ČElKIs, Darius AntanAviČIUs, 1545 metų Livonijos ir Lietuvos Didžiosios Kunigaikštystès sienos patikrinimas (Livonijos pareigūnų ataskaita), Lietuvos istorijos studijos, t. 27: 2011, s. 175.

${ }^{40}$ Ibid., s. 168.

${ }^{41}$ АВАК, т. 3: Акты Брестскаго гродскаго суда, Вильна 1870, № 68, s. 105.

42 Ibid., т. 6: I. Акты Брестского гродского суда (поточные); II. Акты Брестского подкоморского суда; III. Акты Брестской магдебургии; IV. Акты Кобринской магдебургии; V. Акты Каменецкой магдебургии, Вильна 1872, № 8, s. 202, 203; ГСБМ, Выпуск 7, Мінск 1986, S. 112.

${ }^{43}$ Акты, издаваемые коммиссиею, высочайше учрежденною для разбора древнихъ актовъ въ Вильне, т. 1: Акты Гродненскаго земскаго суда, Вильна 1865, № 5, s. 259.

${ }^{44}$ АВАК, т. 14, № 5, s. 72. 
cińce): „дороги великое Клемницкое” (1620 r.) ${ }^{45}$; „дорогою добровольною” $(1598 \text { r. })^{46}$.

W źródłach spotykamy jeszcze jedno określenie używane w stosunku do „drogi” - „путь” ${ }^{47}$ „ „сухимъ путемъ до Городна” (1576 r.) ${ }^{48}$. To określenie („путь”) miało jednak również inne znaczenie - mogło oznaczać osiadłą miejscowość. W 1494 r. w powiecie smoleńskim zostały wymienione właśnie takie miejscowości: „Дубровенскомъ пути, две доли на имя Тугощичи” 49 ; „селца в Смоленскомъ повете в Дубровенскомъ пути на имя Золотович” (1494r.) ${ }^{50}$. Te określenia miejscowości są często wspominane w dokumentach, w których mowa o ziemiach ruskich, szczególnie w okolicach Smoleńska. Dlatego, gdy czytamy źródła, należy pamiętać o tych wyjątkach.

„Drogami wielkimi” (głównymi) i „drogami pospolitymi” nazywano dalekie trakty łączące duże centra polityczne i handlowe ${ }^{51}$. W źródłach często są one prezentowane w sposób opisowy: „дорогою, которая идеть съ Солока у земълю Немецкую” 52 . W dokumentach zdarza się, że „drogami wielkimi” nazywano drogi stosunkowo krótkie: „до гостинца дороги великое, которая идетъ з Вильня до Лаварышокъ” (1595 r.) $)^{53}$. Oznacza to, że droga wielka łączyła Wilno z Ławaryszkami - wsią oddaloną od miasta o około $20 \mathrm{~km}$. Takich przykładów w źródłach jest sporo. W rzeczywistości świadczą one nie o istnieniu specjalnych dróg „wielkich” otaczających większe miejscowości, lecz o tym, że były to odcinki będące częścią dużych dróg przechodzących przez miejscowości i miasteczka. Podany przykład dotyczy sytuacji, w której droga „wielka” z Wilna - przez wspomnianą wieś - prowadziła do Świra (lit. Svyriai). Stąd można odrzucić możliwość istnienia dróg wielkich jedynie na krótkich odcinkach.

Istnieje jeszcze jeden aspekt, który należy podkreślić, gdy mówimy o drogach wielkich, a mianowicie układ tras. Nie zawsze większe miasta leżały przy głównych traktach. Tymczasem podróżujący dążyli do skrócenia czasu podróży i z tego powodu chętnie omijaliby te położone nieco na uboczu miasta (jeśli nie były ich

\footnotetext{
${ }^{45}$ Ibid., т. 11: Акты главного титовского трибунала, Вильна 1880, № 33, s. 93.

${ }^{46}$ Ibid., т. 20: Акты, относящиеся к г. Вильне, Вильна 1893, № 109, s. 145.

${ }^{47}$ ГСБМ, Выпуск 29, Мінск 2009, s. 378.

${ }^{48}$ Aкты, относящиеся к истории Южной и Западной России (1361-1598) (dalej cyt. АЮЗР), т. 1, Санкт-Петербургъ 1863, № 176, s. 207.

${ }^{49}$ Lietuvos Metrika. Knyga Nr. 3 (1440-1498). Užrašymų knyga 3, parengè Lina AnUžYtĖ, Algirdas BALIULis, Vilnius 1998, nr 32, s. 82.

${ }^{50}$ Ibid., nr 33, s. 83; Lietuvos Metrika. Knyga Nr. 4 (1479-1491). Užrašymų knyga 4, parengè Lina ANUŽYtĖ, Vilnius 2004, nr 141.2, s. 155.

${ }^{51} \mathrm{~W}$ dokumencie z 1285 r. zarejestrowano wyjaśnienie tego, co oznacza wyraz „droga wielka” autorstwa mistrza Zakonu: „stratis publicis et viis communibus quibus communiter itur de villa in villam de ciuitate in ciuitatem de castro in castrum nostre domui reseruamus" (Codex diplomaticus Prussicus, Bd. 1, hrsg. v. Johannes VoIgt, Königsberg 1836, Nr. 173, s. 188).

${ }^{52}$ Метрыка Вялікага княства Літоўскага, Кніга № 560. Кніга перапісаў № 3, падрыхт. Алег I. Дзярновіч, Мінск 2007, s. 35, 44.

${ }^{53}$ АВАК, т. 20, № 81, s. 114; № 109, с. 145; ibid., т. 9: Акты Виленского земского суда, магистрата, магдебургии и конфедерачии, Вильна 1878, № 1, s. 10.
} 
celem podróży). Takim przykładem mogą być Troki, które w XVI w. były położone nieco z boku ważnego szlaku handlowego Wilno-Kowno. Dlatego władca WKL w przywileju nadanym Trokom w 1516 r. wskazał, że kupcy podróżujący z Wilna do Kowna powinni jechać przez Troki ${ }^{54}$. Właściciele prywatnych miast także dążyli do tego, by kupcy przejeżdżali przez ich miasta. W 1589 r. w przywileju na prawo magdeburskie nadanym Birżom -mieście należącym do Krzysztofa Radziwiłła „Pioruna” - deklarowano, że droga z Wilna do Rygi powinna prowadzić przez Birże $e^{55}$. Zasada ta znalazła również odbicie w późniejszych dokumentach. W instrukcji wydanej przez Krzysztofa II Radziwiłła w 1621 r. (dla starostów-namiestników jego posiadłości) wspomniano, że „gościniec z Wilna do Ryga na Birże iść ma" ${ }^{\prime \prime}$. A zatem podczas analizy kształtowania się systemu dróg w WKL należy wziąć pod uwagę także wspomniane kwestie.

\section{STAN DRÓG W WIELKIM KSIĘSTWIE LITEWSKIM I ICH URZĄDZENIA}

Po przedstawieniu kwestii językowych odnoszących się do systemu dróg istniejących w WKL ważne jest zrekonstruowanie ogólnego modelu drogi będącej w XV-XVII w. szlakiem komunikacyjnym. Wiele interesujących szczegółów przekazuje rewizja przeprowadzona przez urzędników WKL w 1565 r. Rejestrowała ona szkody wyrządzone przez wojsko, wymieniała m.in. szczegółowy przebieg niektórych traktów. Jednym z nich była: „дорога - отъ Здитова и Спорова у Шчарю реку до верхъ Молчади и Молчадью въ Немонъ, а черезъ Немонъ до Василишок и дорогою Виленскою, ажъ по реку Меречъ, а Меречю внизъ въ Немон, а черезъ Немонъ ажъ до пущъ его кролевское милости, а подле пушчи ажъ в Наревъ, а Нарвою до верху реки Яселъды, Яселдою алижъ до вышей менованого местца Здитова, такъ же и Пинские волости, которые прилегли, где жолънеры досегали, мають списати; въ томъ тракте замъки господарские - Городно, Слонимъ, Лысковъ, Мстибоговъ, а дворы - Волковыйскъ, Зелва, Межиречъ, Острина, Конева, Дубичи, Ейшишки, Радунъ, дворы Городеньские" ${ }^{\prime \prime}$. Na położenie traktu miały więc wpływ konkretne warunki geograficzne oraz rozwój miejscowości. Świadczą o tym rzeki wymienione na danym szlaku. Na drodze tej nie było mostów, istniały natomiast przeprawy lub brody. Stanowiły one swoiste „skrzyżowania” dróg i rzek ${ }^{58}$. Poza tym w opisie

${ }^{54}$ Lietuvos Metrika. Knyga Nr. 9, nr 553.(15), s. 306. Także: Lietuvos magdeburginiu miestu privilegijos ir aktai (dalej cyt. LMMPA), t. 6: Trakai, sudare Algirdas Balıulis, Vilnius 2008, nr 238, s. 279 ; nr 104, s. 227.

${ }^{55}$ D. Karvelis, Laiškas, s. 12.

${ }^{56}$ Instrukcijos feodaliniu valdu administracijai Lietuvoje, parengè Zigmantas KIAUPA, Jūratè KiAupienĖ, Vilnius 1985, nr 1, s. 3; nr 11b, s. 34.

${ }^{57}$ РИБ, т. 30, № 86 , s. 802, 804.

${ }^{58}$ Zob. L. Karalius, Privatūs muitai, s. 274; Linda Doran, Medieval Communication Routes Through Longford and Roscommon and Their Associated Settlements, Proceedings of the Royal Irish Academy. Section C, Archaeology, Celtic studies, vol. 104, no. 3, Dublin 2004, s. 61-64. 
wspomina się, że droga prowadziła wzdłuż „puszczy królewskiej” - omijała więc tereny trudne do przejścia.

Mosty wspomniane w systemie dróg WKL L. Karalius podzielił na kilka kategorii: zwykłe mosty drewniane wykonane $\mathrm{z}$ belek drewnianych opartych na brzegach mniejszych rzek; mosty pontonowe używane głównie w czasach wojen; drewniane mosty budowane na palach prowadzone przez duże rzeki; mosty na trwałych oparciach drewnianych lub murowanych; wyróżniono także kategorię mostów kamiennych ${ }^{59}$. Sporo z tych obiektów zostało utrwalonych w materiale ikonograficznym ${ }^{60}$.

Kolejnym drogowym urządzeniem inżynieryjnym, które służyło ulepszeniu ówczesnych szlaków komunikacyjnych, była „gać drewniana” („гать”, „gać”) ${ }^{61}$. Jest to odcinek drogi wyłożonej gałęziami, pniami i bierwionami w grząskich miejscach. W języku litewskim istnieje wyraz „kamša”, który oznacza drogę w grząskich lub bagnistych miejscach usłaną witkami, tyczkami, bierwionami ${ }^{62}$. Ten lituanizm spotykamy w dokumencie pochodzącym z lat czterdziestych XVI w., na mocy którego $\mathrm{w}$ powiecie kowieńskim potwierdzono dobra nadane szlachcie skorulskiej (lit. Skaruliai) i zaznaczono granice: „привели насъ тою дорогою на мостак, Ко-

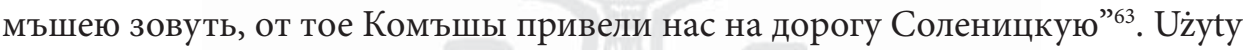
w źródle wyraz „Комъша” jest bliski znaczeniowo wyrazowi „mostek”. Dlatego należy się zgodzić z L. Karaliusem, że groble drewniane w poszczególnych przypadkach nazywano po prostu „mostami”" Zwłaszcza że o tych „mostach” wspomniano w Wegeberichte zakonu krzyżackiego z XIV w. ${ }^{65}$

Te inżynieryjne urządzenia służyły podróżnym w sezonie, gdy pogoda była wilgotna, co oznaczało konieczność naprawy i wzmocnienia zalanych i nieprzejezdnych dróg. W nakazie hospodara dla zarządcy Merecza Michała Jundziłła pochodzącym z lat czterdziestych XVI w. wspomina się o tym, że powołana została komisja WKL, której zadaniem (razem z posłami pruskimi) było wyznaczenie odcinka granicy przy rzece Merecza i dlatego: „на реках и на болотах, и на инъшых

${ }^{59}$ L. Karalius, Tiltai, s. 9-14.

${ }^{60}$ Zob. Povilas RekLaitis, Prarastosios Lietuvos pédsakų beieškant, Vilnius 1999, s. 191, 193, 195, 255; Вялікае Княства Літоўскае эниьклапедья, т. 1, Мінск 2005, s. 18, 130, 313, 377, 438; т. 2, Мінск 2006, s. 106, 458, 598, 647, 676; VUB, RS, sygn. F23-135.

${ }^{61}$ L. Karalius, Tiltai, s. 14-15. Także: Aкmы, относящиеся к истории Западной России (1544-1587), т. 3, Санкт-Петербургъ 1848, № 97, s. 225-226; Археографический сборникъ документовъ относящзия к истории Северо-Западной Руси (dalej суt. АСДСЗР), т. 8, Вильна 1870, № 70, s. 305; ГСБМ, Выпуск 6, Мінск 1985, s. 258; Słownik staropolski, t. 2, s. 374.

${ }^{62}$ Lietuvių kalbos žodynas (dalej cyt. LKŽ), t. 5, Vilnius 1959, s. 184.

${ }^{63}$ Lietuvos Metrika (1540-1543). 12-oji Teismy bylu knyga (XVI a. pabaigos kopija), parengè Irena Valikonyté, Neringa Šlimienė, Saulè Viskantaitė-SaViščeviené, Lirija Steponavičienė, Vilnius 2007, nr 177, s. 158.

${ }^{64}$ L. Karalius, Tiltai, s. 17-18.

${ }^{65}$ Die littauischen Wegeberichte, [in:] Scriptores rerum Prussicarum, Bd. 2, hrsg. v. Theodor Hirsch, Max Töppen, Ernst Strehlke, Liepzig 1863, S. 668; T. ČElkis, Keliais po viduramžiu Lietuva. II., s. 125-137. 
трудъных местцах ку перебыванью мосты и гати робити, и дороги, куды оные комисары нашы мають ехати"66. Wzmocnienie nawierzchni dróg stosowano w zależności od warunków geograficznych. L. Karalius na podstawie świadectwa Bernarda Tannera (posła Rzeczypospolitej do Rosji) pochodzącego z 1678 r. wskazał, że na odcinku drogi od Smoleńska do Wiaźmy dyplomata naliczył 53 gaci, a długość niektórych sięgała 5-6 km². Powyższy przykład pokazuje, że tego typu umocnienia dróg trafiały się często, a część z nich istniała na dużych odległościach. Z kolei w dzienniku podróży do Moskwy dyplomaty cesarskiego Francesca Da Colla z czerwca 1518 r. zanotowano, że od Brześcia Litewskiego zaczynały się duże mokradła, dlatego przez cały dzień jechano „drewnianą drogą" ${ }^{68}$. Jednak trudno sobie wyobrazić, by gaci mogły być takie długie. Tę wątpliwość rozwiewają mapy Kurlandii i części Inflant sporządzone przez szwedzkich kartografów w 1695 r. Na jednej z nich narysowano drogę Birże-Bauska, na której wyraźnie widać długie drewniane odcinki trasy ${ }^{69}$. Na planie zaznaczono mokradło, przez które prowadziła droga. Warto zaznaczyć, że oznaczone na mapach drewniane odcinki traktów prowadziły także przez różne miejscowości. Więc i ich mieszkańcy mogli korzystać z tych ulepszonych odcinków dróg.

Laimontas Karalius opisując warunki połączeń drogowych w WKL, wyróżnia jeszcze jedno drogowe urządzenie inżynieryjne - „groblę” („гробля”, „grobla”70), czyli wał ziemny (wzmocniony często drewnem i faszyną), po którym przebiega droga $^{71}$. Informacje o groblach występujące w źródłach są zwykle bardzo enigmatyczne. Niemniej dysponujemy ciekawym źródłem ikonograficznym z XVII w., jakkolwiek pochodzącym z terenów Inflant, przedstawiającym okolice Bowska (łot. Bauska) ${ }^{72}$. Na planie przedstawiono przekrój grobli z ukazaniem warstw, z których została zbudowana. Na obrzeżach grobli zaznaczono rowy służące

${ }^{66}$ Lietuvos Metrika. 12-oji Teismų bylų knyga, nr 107, s. 102. Także: Lietuvos Metrika. Knyga Nr. 8 (1499-1514). Užrašymų knyga 8, parengè Algirdas BAliUlis, Romualdas Firkovičius, Darius Antanavičıus, Vilnius 1995, nr 594, s. 436; Метрыка Вялікага Княства Літоўскага. Кніга 28 (1522-1552). Кніга запісаў 28, падрыхт. Валеры Мянжынскі, Уладзімір Свяжынскі, Мінск 2000, № 15 , s. 63 .

${ }^{67}$ L. Karalius, Tiltai, s. 15; Poselstwo polsko-litewskie do Moskwy w roku 1678 szczęśliwie przedsięwzięte, opisane przez naocznego świadka Bernaeda Tannera, oprac. Aleksander STroJny, Michał RzEPIELA, Kraków 2002, s. 147-160.

${ }^{68}$ Francesco da Collo. Relazione del viaggio e dellambasciata in Moscovia, 1518-1519, a cura di Giampaolo Zagonel, D. De Bastiani 2005, s. 48; Rūstis Kamuntavičıus, XVI a. pirmosios pusés imperatoriaus pasiuntinys Frančeskas Da Kolas, Lietuva ir tarpininkavimo misija Maskvoje, [in:] Lie-

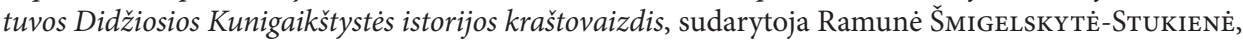
Vilnius 2012, s. 246.

${ }^{69}$ LVVA, F. 7040, Apraksts (dalej cyt. Apr.) 1, Lieta (dalej cyt. L.) 2193, k. 27.

${ }^{70}$ Lietuvos Metrika. Knyga Nr. 14 (1524-1529). Užrašymų knyga 14, parengè Laimontas KARALIUs, Darius Antanavičius, Vilnius 2008, nr 849, s. 360. Także: АСДСЗР, т. 8, № 70, s. 305. W słownikach podaje się, że pojęcie to mogło oznaczać: rów, kopiec, tamę itp. Zob. ГСБМ, Выпуск 7, s. 144; Słownik staropolski, t. 2, s. 489-490.

${ }^{71}$ L. Karalius, Tiltai, s. 19; LKŽ, t. 3, Vilnius 1956, s. 638.

${ }^{72}$ LVVA, F. 2909 , Apr. 1, L. 112. 
do odprowadzania nadmiaru wody. Grobla składała się z pięciu warstw: przede wszystkim bagnistą powierzchnię wyłożono poziomo bierwionami; na nich ułożono drugą warstwę - gałęzie jodeł lub sosen oraz mniejsze bierwiona; na trzecią warstwę składała się ziemia, którą wykopano z obrzeży grobli podczas kopania rowów odprowadzających wodę; na wysypanej ziemi wyłożono jeszcze jedną warstwę gałęzi i drobniejszych bierwion; wreszcie ostatnią grubą warstwę stanowił jasny utwardzony żwir ${ }^{73}$. Tak zbudowane groble musiały istnieć tė̇ w tym okresie $\mathrm{w}$ WKL, tym bardziej że podobna grobla została przedstawiona na ilustracji powstałej podczas rewizji dróg w WKL w 1766 r. ${ }^{74}$ Omówione umocnienia dróg wskazują na to, że starano się usprawnić połączenia drogowe w kraju. Zrozumiałe jest jednak, że nie wszędzie drogi były w równym stopniu uporządkowane. O stan dróg w poszczególnych miejscowościach troszczyła się ludność lokalna i nie zawsze stać ją było na samodzielną ich naprawę. Stąd często zwracano się do władcy z prośbą o pozwolenie na pobieranie ceł na mostach, by za uzbierane pieniądze można było pokryć koszty naprawy ${ }^{75}$. A wielcy książęta litewscy w trosce o stan dróg w WKL odpowiadali zwykle na takie prośby pozytywnie. W 1542 r. na mocy przywileju hospodara książę Wasyl Andrejewicz Połubieński uzyskał pozwolenie na pobieranie cła mostowego (grobelnego) na odcinku dużej drogi: od jego posiadłości do Połubicza, ponieważ wskazano, że wzmocnienie drogi się załamało i należy je odnowić ${ }^{76}$.

Poprawa połączeń drogowych była aktualna w deszczową porę roku, ponieważ gdy przymrozki skuwały ziemię, wiele tego typu problemów rozwiązywało się samoistnie. W 1647 r. król Władysław IV nakazał mieszkańcom miasteczka Simno (lit. Simnas), by w puszczy królewskiej narąbali drewna i wykonali wzmocnienie dróg w okolicach miasta, ponieważ znajdowało się ono w kotlinie i z powodu deszczu drogi stały się nieprzejezdne ${ }^{77}$. W dokumentach istnieje podział na drogi letnie i zimowe. W 1586 r. w województwie brzeskim na granicy z Polską, między wsiami Szack i Orzechowo wspomniana została droga zimowa: „где впала дорога зимняя въ болото до Песка"78. Najczęściej drogi zimowe prowadziły przez bagna. W 1504 r. w opisie ziem w okolicach Dubicz należących do Wasyla Glinskiego wskazano: „сеножать нашу Дубицкую на болоте, от Божатновых сеножатеи, от реки Озабочи по дорогу зимнюю, што идеть через тое болото, которою

${ }^{73}$ Ibid. Dziękuję dr. Siergiejowi Polechowowi za pomoc w odczytaniu zapisów.

${ }^{74}$ LVIA, f. Senieji aktai, byla nr 3939, k. 370.

${ }^{75}$ L. Karalius, Privatūs muitai, s. 263-276; idem, Kam reikalingos valdovu privilegijos Lietuvos Didžiojoje Kunigaikštystèje? Lucko miestiečiu 1469 m. Kazimiero Jogailaičio privilegijos dèl nauju muitu draudimo Voluineje teisinis, politinis ir ekonominis kontekstas 1469-1547 m., [in:] Istorijos šaltiniu tyrimai, t. 4, sudarè Artūras Dubonis, Vilnius 2012, s. 63-90.

${ }^{76}$ Метрыка Вялікага Княства Літоўскага, Кніга 28, № 15, s. 63.

${ }^{77}$ LMMPA, t. 8: Lazdijai. Simnas, parengè Jonas Drungilas, Vilnius 2013, nr 48, s. 179-180.

${ }^{78}$ ABAK, т. 6, № 2, s. 146. 
ж дорогою зиме к Дубичом сено возят"79 - zatem dopiero po zamarznięciu bagien można było przewieźć siano.

Mobilność mieszkańców rosła więc w zależności od sezonu. Podróżnik angielski Fynes Moryson na początku XVII w. twierdził, że Litwa obfituje w bagna i lasy, a miejscowości są bardzo oddalone od siebie aż o 20 mil niemieckich, dlatego nie można po niej podróżować latem, a tylko zimą, gdy wszystko zamarza ${ }^{80}$. Można z tego wnioskować, że istnienie opisanych udogodnień umacniających i utwardzających drogi nie było powszechne. Polepszenie stanu dróg sporo kosztowało i prawdopodobnie najszybciej naprawiano drogi, które były istotne z punktu widzenia strategicznego i ewentualnie handlowego. Część dróg zaś prowadziła prosto przez pola, nawet zdarzało się, że były one zaorane ${ }^{81}$.

W tej części artykułu należy omówić jeszcze kilka aspektów, które świadczyły o usprawnieniu systemu komunikacji w WKL. Siedemnastowieczne źródła ikonograficzne dotyczące Inflant wskazują, że takie ośrodki administracyjne i handlowe jak Ryga, na drogach prowadzących do nich, stosowały specjalne znaki drogowe wskazujące podróżnikom kierunki i odległości do miasta ${ }^{82}$. Stworzony system znaków pomagał w ustaleniu odległości, co w sposób oczywisty było podyktowane potrzebą oszczędzania czasu podczas podróży. Znaki drogowe przedstawione na planie okolic Bowska z drugiej połowy XVII w. wskazywały drogę w kierunku Rygi $^{83}$. Były to słupy wkopane w ziemię i pomalowane na czerwony kolor. Na nich umieszczono herb Rygi, a także pozostającą do tego miasta odległość w milach. Ten przykład przywodzi na myśl, by w analogiczny sposób odbierać niektóre wzmianki zawarte w źródłach pisanych pochodzących z terenu WKL mówiące o oznakowaniu dróg. Niektóre dane w tym względzie sięgają jeszcze czasów panowania wielkiego księcia Witolda. W opisie brodu przez Dźwinę z 1557 r. wspomniano odcinki dróg prowadzące z Litwy w kierunku Rusi i wskazano, że nieopodal granicy z Połockiem istniał bród, przez który przeprawiał się książę Witold z wojskiem w kierunku Nowogródka i Moskwy oraz że wciąż stoją tam „krzyże”84. Możliwe, że odgrywały one rolę znaków drogowych. W 1526 r. podczas oznaczania granic wspomniany został murowany słup: „подле Еишишъского [...] дорогою великою виленьскою подле столъпа мурованого"85. W 1559 r. podczas rewizji pustkowi w WKL w opisie ziem nieopodal Pińska wskazano słup przy moście:

${ }^{79}$ Lietuvos Metrika. Knyga Nr. 5 (1427-1506). Užrašymų knyga 5, parengè Algirdas Baliulis, Artūras Dubonis, Darius Antanavičius, Vilnius 2012, nr 558, s. 373; Lietuvos Metrika. Knyga Nr. 51, nr 146, s. 202.

${ }^{80}$ Fynes Moryson, An Itinerary Containing His Ten Yeers Travell through the Twelve Dominions of Germany, Bohmerland, Switzerland, Netherland, Denmarke, Poland, Italy, Turky, France, England, Scotland \& Ireland, vol. 4, Glasgow 1908, s. 68.

${ }^{81}$ АВАК, т. 22: Акты Слонимского земского суда, Вильна 1895, № 538, s. 287.

${ }^{82}$ LVVA, F. 6828, Apr. 2 (1), L. 5a.

${ }^{83}$ Ibid., F. 2909, Apr. 1, L. 91, k. 2.

${ }^{84}$ АЮЗР, т. 1, № 132, s. 140.

${ }^{85}$ Lietuvos Metrika. Knyga Nr. 14, nr 607, s. 248. 
„до мосту и столпа, которы мостъ на дорозе Клецкой"86. Słupy murowane zostały wspomniane także przy drodze Wilno-Niemież w źródle pochodzącym z 1598 r. ${ }^{87}$ i przy drodze wielkiej z Wilna do Rudnik w 1675 r. ${ }^{88}$ Dane te nasuwają przypuszczenie, że w poszczególnych przypadkach przy mostach, skrzyżowaniach i na obrzeżach miast mogły być stawiane specjalne znaki drogowe. Taki znak drogowy został zaznaczony na rysunku drogi Birże-Bowsk pochodzącym z 1695 r. ${ }^{89}$ - był to słup, na którym była określona odległość 3\%3 mili. Informacje te pozwalają stwierdzić, że na niektórych drogach w WKL stawiano znaki drogowe.

W dokumencie z 1534 r. omawiającym ustanowienie dóbr prywatnych wspomniane zostały krzyże przydrożne: „до двора Ганусишъского, мимо ворота улицою троцкою, аж до крижа. Отъ крижа межою подле поль медвишъских и къ полю Ганусишъскому межою аж до крижа другого, который стоить на дорозе Довкговской"90. Zapewne były to oznakowania granic w postaci krzyży. Nie jest to jednak opinia jednoznaczna. Badania Liudasa Jovaišy wskazują, że w XVII w. celowo stawiano krzyże i kapliczki przy drogach czy na obrzeżach miasteczek ${ }^{91}$. Zatem również obiekty o takim charakterze mogły być elementem infrastruktury drogowej.

\section{SCHEMAT STRUKTURY DRÓG LĄDOWYCH \\ W WIELKIM KSIĘSTWIE LITEWSKIM - PRZYKŁAD WILNA}

Układ traktów lądowych w dużej mierze zależy od rozwoju osadnictwa. Dlatego ze zmianami zachodzącymi w zasiedleniu kraju część dróg nieuchronnie się zmieniała $^{92}$. W XVI w. w trakcie rozwoju kolonizacji wewnętrznej na nowo zdobytych ziemiach zakładano wsie i dwory, powstawały miasteczka ${ }^{93}$. Aby lepiej zrozumieć, jak funkcjonował system dróg w WKL, warto przeanalizować to na przykładzie traktów połączonych z ważnym ośrodkiem miejskim. Ze względu na wielkość i znaczenie gospodarcze, a także specyficzne położenie geograficzne, wreszcie fakt

${ }^{86}$ Ревизия пуш и переходов звериных в бывшем Великом Княжестве Литовском, с присовокуплением грамот и привилегий на входы в пущи и на земли, составленная Григорием Богдановичем Воловичем в 1559 году, с прибавлением другой актовой книги, содержашей в себе привилегий, данныя дворянам и священникам Пинскаго повета, составленной в 1554 году. Виленская археограбическая коммиссия, Вильна 1867, s. 8.

${ }^{87}$ АВАК, т. 20, № 109, s. 145.

${ }^{88}$ Ibid., т. 10: Акты Виленского магистрата и магдебургии, Вильна 1879, № 104, s. 412. Zob. także: ibid., т. 22, № 538, s. 286-287; Материалы для терминологчческого словаря древней России, составил Георгий Е. Кочин, Москва-Ленинград 1937, s. 345; L. Karalıus, Tiltai, s. 5.

${ }^{89}$ LVVA, F. 7404, Apr. 1, L. 2193, k. 30.

${ }^{90}$ Lietuvos Metrika (1533-1535). 8-oji Teismų bylų knyga, parengè Irena VALIKonytė, Stanislovas LazutKa, Neringa Šlimienė, Jolanta KarpavičıenĖ, Jurgita ŠaučIūnaitė, Saulè Viskantaitė, Vilnius 1999, nr 365, s. 171.

${ }^{91}$ Liudas JovaIšA, Nuo Giedraičio iki Tiškevičiaus: katalikiškoji Reforma Žemaičiu vyskupijoje [oddane do druku]; Žemaičių vyskupijos vizitacijų aktai (1611-1651 m.), parengè idem, Vilnius 2011, s. $379,380,385,394,395,396$.

${ }^{92}$ Por. przyp. 27.

${ }^{93}$ Zob. S. Alexandrowicz, Geneza, s. 19-93. 
stosunkowo dobrze zachowanej bazy źródłowej stołeczne Wilno wydaje się bardzo dobrym przykładem do analizy.

W źrodłach wyróżnione są drogi wielkie i pospolite zmierzające do Wilna. W XVI w. napotykamy wzmianki o różnych głównych traktach powiązanych z tym stołecznym miastem: „miesczanie Grodzieńscy tą drogą do Pruss dobrowolnie iezdzić” (1516 r.) $)^{94}$; „к великои дорозе, которая идеть зъ Литвы къ Берестю” (1523 r. $)^{95}$; „до дороги великой съ Вилна на Русь” (1592 r.) ${ }^{96}$. Określenia dróg wskazują, że Wilno stanowiło zarówno początek ważnych dróg, jak i niekiedy było miastem tranzytowym w wypadku innych dłuższych szlaków lądowych. Drogi te - jak się wydaje - łączyły często całe regiony, by odwołać się do ostatniego przykładu: „съ Вилна на Русь”. Dlatego w pierwszym rzędzie należy omówić wielkie drogi łączące odległe ośrodki miejskie, więc w tym wypadku Wilno z innymi miastami, ponieważ w ten sposób można poznać sieć dróg regionalnych, z którymi stolica WKL była szczególnie powiązana.

Jedną z ważniejszych magistrali był gościniec z Wilna do Połocka. Trakt został wspomniany już w 1437 r. ${ }^{97}$, a w 1664 r. pisano, że droga prowadziła przez Rokanciszki: „до дороги гостинца Полоцкого, названой Рокантисокой”98. W innym przypadku podano, że z Połocka do Wilna można było jechać przez Mołodeczno (1488 r. $)^{99}$. Przez Połock podróżowano również z Wilna do Moskwy ${ }^{100}$. W źródłach wspomniano też trasę Wilno-Witebsk ${ }^{101}$. Możliwe, że do Witebska podróżowano również przez Połock.

Inna wielka droga to Wilno-Brasław $\left(1559\right.$ r) ${ }^{102}$. W źródłach nie wspomina się o niej tak często jak o trakcie do Połocka, ale jest ona zawsze nazywana „drogą

${ }^{94}$ АВАК, т. 7, № 6, s 67; Lietuvos Metrika. Knyga Nr. 37 (1552-1561). Užrašymų knyga 37, parengè Darius BARONAs, Vilnius 2011, nr 217, s. 258.

${ }^{95}$ Lietuvos Metrika. Knyga Nr. 12 (1522-1529). Užrašymų knyga 12, parengė Darius AnTANAvičıus, Algirdas Baliulis, Vilnius 2001, nr 253, s. 260.

${ }^{96}$ АВАК, т. 14, № 53, s. 448; АСДСЗР, т. 11, Вильна 1890, № 22, s. 27.

${ }^{97}$ Liv,- Est- und Curländisches Urkundenbuch, Bd. 9, hrsg. v. Hermann Hildebrand, Riga-Moskau 1889, Nr. 153, s. 98.

${ }^{98}$ АВАК, т. 20, № 278, s. 374; т. 9, № 29, s. 98.

${ }^{99}$ Памятники дипломатических сночений древней России съ державами иностранными. Памятники дипломатических сношений Московскаго государства съ Польско-Литовскимб государствомь (1487-1533). Сборник Императорскаго Русскаго Историческаго Общества, т. 35, Санкт-Петербургъ 1882, № 2, s. 10.

100 Sigismund von Herberstein: Rerum Moscoviticarum Commentarii. Synoptische Edition der lateinischen und der deutschen Fassung letzter Hand Basel 1556 und Wien 1557, unter der Leitung v. Frank Kämpfer erstellt v. Eva Maurer, Andreas Fülberth, redigiert und hrsg. v. Hermann Beyer-Тнома, München 2007, s. 245; Хронологический указатель указов и правительственных распоряжений по губерниям Западной России, Белоруссии и Малороссии за 240 лет, с 1652 по 1892 год, составил Симон Ф. Рубинштейн, Вильна 1894, № 53, s. 19; Памятники дипломатических сношений древней России, т. 35, № 11, s. 43.

101 Витебская старина, т. 1, составилъ Алексей П. Сапуновъ, Витебскъ 1883, № 152, s. 322 .

${ }^{102}$ Lietuvos Metrika. Knyga Nr. 37, nr 225, s. 261. 
wielką"103. O jej znaczeniu świadczy również to, że była zaznaczona na mapach siedemnastowiecznych. Wskazywano, że prowadzi przez Wiłkomierz (lit. Ukmergè), Onikszty (lit. Anykščiai) itd. aż do Brasławia ${ }^{104}$. Niekiedy w źródłach wspominana jest droga Wiłkomierz-Wilno, która musi być częścią traktu do Brasławia ${ }^{105}$.

Z Wilna prowadziła też wielka droga do Mińska: „wielikoie dorohi Wilenskoie od Menska" (1518 r.) ${ }^{106}$. W nieunikniony sposób musiała prowadzić przez mniejsze ośrodki. W dokumentach są wzmianki o następujących drogach prowadzących w tym kierunku: „дороги на Крево зъ Вильна” (1607 r.) ${ }^{107}$; Wilno-Oszmiana (przez Miedniki) ${ }^{108}$. W 1702 r. wspomniana została droga wielka Wilno-Holszany (lit. Alšènai)-Mińsk ${ }^{109}$. W inwentarzu Smorgoń (lit. Smurgainiai) jest wzmianka o ulicy Wileńskiej, która także świadczy o możliwym przebiegu tu traktu Wilno-Mińsk ${ }^{110}$.

W kierunku ziem ruskich z Wilna prowadziła też droga wielka do Mołodeczna $(1590 \text { r. })^{111}$. W innym źródle wspomniano o drodze wielkiej Wilno-Ostrowiec $(1556 \text { r. })^{112}$, znajdującej się w tej okolicy, która także mogła być częścią składową dalekich traktów, podobnie jak droga wielka w kierunku Świra ${ }^{113}$. W źródle z 1565 r. wspomniano również o drodze Wilno-Miadzioł (biał. Мядзель) ${ }^{114}$.

Inne drogi wielkie idące w kierunku terytoriów ruskich to trakty: Wilno-Nowogródek (przez Gieranony (lit. Geranainiai) ${ }^{115}$ ) i Wilno-Grodno ${ }^{116}$. Z Grodna dalej droga wielka prowadziła do Warszawy ${ }^{117}$. Ten ostatni trakt jest wspomniany już

${ }^{103}$ ABAK, т. 6, № 6, s. 170; № 32, s. 282.

${ }^{104}$ LVVA, F. 2909, Apr. 1, L. 1030, k. 1; Exposé du conflit Lithuano-Polonais. Deuxième assemblée de la société des nations a Genève, Genève 1921 (załącznik - mapa); J. MaroszeK, op.cit., s. 165.

${ }^{105}$ АВАК, т. 13: Акты главного литовского трибунала, Вильна 1886, № 38, s. 115.

${ }^{106}$ Ibid., т. 33: Акты, относящиеся к истории западно-русской иеркви, Вильна 1908, № 15, s. 23 ; т. 11, № 102 , s. 282.

${ }^{107}$ Ibid., т. 18: Акты о копных судах, Вильна 1891, № 198, s. 212.

${ }^{108}$ Нацыянальны гістарычны архіў Беларусі, фонд 1928, опис. 1, д. 1, л. 137-138; АВАК, T. 11, № 112 , s. 356.

${ }^{109}$ АВАК, т. 11, № 110, s. 339.

${ }^{110}$ Инвентари магнатских владений Белоруссии XVII-XVIII вв. Владение Сморгонь, Минск 1977, № 3, s. 35; № 5, s. 73.

111 АВАК, т. 36: Акты Минского гродского суда (1582 и 1590 г2.), Вильна 1912, № 457, s. 384 .

${ }^{112}$ Метрыка Вялікага Княства Літоўскага, Кніга 43 (1523-1560). Кніга запісаў 43, падрыхт. Валеры Мянжынскі, Мінск 2003, № 27, s. 79.

${ }^{113}$ АСДСЗР, т. 10, Вильна 1874, s. 156.

114 РИБ, т. 30, № 87, s. 805.

${ }^{115}$ Lietuvos Metrika. Knyga Nr. 14, nr 849, s. 360; Метрыка Вялікага Княства Літоўскага, Kнiza 43, № 21, s. 68.

${ }^{116}$ Lietuvos Metrika (1540-1541). 10-oji Teismų bylų knyga, parengè Stanislavos LAzuTKA, Irena VAlikonytė, Saulè Viskantaitė-SaviščEVienĖ, Jolanta KARPaVČIEnĖ, Vilnius 2003, nr 166, s. 105; Hansische Handelsstrassen, [Tl. 2], s. 658-659.

117 Zob. źródła kartograficzne: LVVA, F. 2909, Apr. 1, L. 1030, k. 1. Exposé du conflit Lithuano-Polonais (załącznik - mapa); Hansische Handelsstrassen, [Tl. 2], s. 700. 
w źródłach pochodzących z czasów panowania Witolda ${ }^{118}$. Z Grodna prowadziła też trasa do Królewca ${ }^{119}$. Należy dodać, że z Wilna biegła także droga do Brześcia, a stamtąd dalej do Krakowa ${ }^{120}$. Możliwe, że z Wilna do Brześcia jeżdżono przez Grodno. W tym kierunku prowadziła także wzmiankowana w źródłach droga Wilno-Pińsk ${ }^{121}$.

Zrozumiałe jest, że dalekie drogi wielkie i drogi pospolite przebiegały przez mniejsze centra i w ten sposób powstawały całe szlaki. O tym świadczy przebieg wspomnianej drogi wielkiej Wilno-Oszmiana, na trasie której znajdowała się wieś Żuprany (biał. Жупраны), stąd w źródłach pierwszy odcinek został nazwany wielkim szlakiem Żuprany-Wilno (1557 r.) $)^{122}$. Widzimy to również na przykładzie innych miasteczek, dworów i wsi położonych nieopodal Wilna, które ze stołecznym miastem łączyła droga nazywana gościńcem lub drogą wielką. Dotyczyło to np.: Eiszyszek - „гостинцу Виленъского, ку реце Дитьве, едучы от Рауни до Ейшишок” (1562 r.) ${ }^{123}$; Miednik ${ }^{124}$, Ławaryszek ${ }^{125}$, Skajster (lit. Skaisteriai) ${ }^{126}$, Niemieża $^{127}$ i Rudnik $^{128}$, a także posiadłości leżących w pobliżu wielkich dróg, jak np. włości Kiena (lit. Kena) leżącej nieopodal „дороги великой съ Вилна на Русь” $(1592 \text { r. })^{129}$. Ciekawe, że źródła milczą na temat drogi z Wilna do Lidy. Jedynie Adam Kirkor w swojej pracy o Wilnie z XIX w. wymienił drogę Wilno-Lida, lecz nie wiadomo, na ile stary był to trakt, gdyż autor nie przywołał źródła tej informa$\mathrm{cji}^{130}$.

Osobno należy omówić gościńce i drogi wielkie prowadzące z Wilna do obszarów nieruskich. Wspomnieć trzeba przede wszystkim o drodze wielkiej Kowno-Wilno, którą często wymienia się w źródłach ${ }^{131}$. Był to szlak bezpośrednio łączący obydwa miasta. Oprócz tego istniała inna droga wielka łącząca te miasta, która

${ }^{118}$ Lites ac res gestae inter Polonos Ordinemque Cruciferorum, t. 2, ed. Ignacy Zakrzewski, Posnaniae 1892, s. 164; Документы и регесты к истории литовских евреев (1388-1550). Русскоеврейский архив, т. 1, Санкт-Петербургъ 1882, № 66, s. 90.

${ }^{119}$ Lietuvos Metrika. Knyga Nr. 51, nr 229, s. 319; Hansische Handelsstrassen, [Tl. 2], s. 632.

120 Документы Московскаго архива Министерства юстииии, т. 1, подготовил Митрофан В. Довнар-Запольский, Москва 1897, № 17, s. 206; АСДСЗР, т. 11, № 47, с. 51.

121 3.Ю. Копысский, op.cit., s. 153.

${ }^{122}$ Метрька Вялікага Княства Літоўскага, Кніга 43, № 35, s. 83; № 36, s. 83.

${ }^{123}$ Lietuvos Metrika. 10-oji Teismų bylų knyga, nr 4, s. 23.

${ }^{124}$ ABAK, T. 11, № 34, s. 96.

${ }^{125}$ Ibid., T. 20, № 81, s. 114.

${ }^{126}$ Ibid., т. 8: Акты Виленского гродского суда, Вильна 1875, № 168, s. 418.

${ }^{127}$ Ibid., т. 20, № 109, s. 145.

128 Lietuvos Metrika. Knyga Nr. 20 (1536-1539). Užrašymų knyga 20, parengè Raimonda Ragauskienė, Darius Antanavičius, Vilnius 2009, nr 116, s. 177; ABAK, т. 30: Акть Троискаго подкоморскаго суда за 1585-1613 годы, Вильна 1904, № 12, s. 55; J. MARoszeк, op.cit., s. 166.

${ }^{129}$ АВАК, т. 14, № 53, s. 448.

${ }_{130}$ Адам К. Киркор, Историко-статистическіе очерки города Вильно, [in:] Въ память пребыванія государя императора Александра II въ Вильне 6 и 7 сентября 1858 г. Изданіе Виленской арчеологической камиссіи, Вильно 1858, s. 63.

${ }^{131}$ Метрька Вялікага Княства Літоўскага, Кніга 43, № 31, s. 81; № 34, s. 82. 
prowadziła przez Troki. Jak wspomniano, litewscy władcy usiłowali włączyć do systemu ważnych szlaków handlowych Troki. Świadczy o tym przywilej nadany temu miastu w 1516 r., na mocy którego nakazano kupcom jadącym z Kowna do Wilna przejeżdżać przez Troki ${ }^{132}$.

Z Wilna prowadziły też drogi wielkie do Wiłkomierza ${ }^{133}$ (a stąd dalej do Upity $^{134}$ ); Giedrojć (przez Rzeszę) ${ }^{135}$, Łabonar (lit. Labanoras) ${ }^{136}$. Chociaż źródła nie podają tego wyraźnie, to jest mocno prawdopodobne, że te wielkie drogi stanowiły odcinki dalekich traktów, podobnie jak to było z traktami prowadzącymi w kierunku terytoriów ruskich.

Z Wilna prowadził bardzo ważny z punktu widzenia ekonomicznego gościniec do Rygi. Łączył on też Wilno z Birżami, jak wynika z instrukcji wydanej przez Krzysztofa Radziwiłła w 1621 r. dla zarządców jego żmudzkich posiadłości ${ }^{137}$.

Ponadto w dokumentach mówi się o drodze prowadzącej z Wilna do radziwiłłowskich Kiejdan, lecz było to zapewne odgałęzienie odchodzące od drogi wielkiej ${ }^{138}$. W źródłach wymieniono też drogę z Wilna do Olity ${ }^{139}$. Możliwe, że ta droga prowadziła do Merecza, a stamtąd dalej do Grodna, ponieważ wiadomo, że z Wilna istniała droga do Merecza przez Dowgi (również Daugi, lit. Daugai) ${ }^{140}$.

Rozwój dróg wielkich i gościńców był wynikiem konieczności połączenia ważniejszych ośrodków miejskich. Świadczą o tym nazwy dróg wielkich, takich jak np. Wilno-Pińsk, Wilno-Witebsk czy Wilno-Ryga.

Oprócz dróg głównych do Wilna prowadziły osobne niedalekie drogi, które łączyły bezpośrednio stolicę z miejscowościami leżącymi w jej pobliżu. Jako przykład można wymienić drogę wspomnianą już w źródłach szesnastowiecznych Wilno-Suderwa-Kiernów: „зъ Вилна до того дворца Судервского едучиб за Глинишомъ по правой руце [...] черезъ реку Рандовупою, мимо Мшариня, аж до дороги Керновское” (1593 r. $)^{141}$, lub trakt biegnący do Rokanciszek ${ }^{142}$, a także inne przykłady: „подле дороги, едучи до места Виленского одъ Алекупе” (1593 r.) ${ }^{143}$;

${ }^{132}$ Lietuvos Metrika. Knyga Nr. 9, nr 553.(15), s. 306; LMMPA, t. 6: Trakai, sudare Algirdas BALIULIS, Vilnius 2008, nr 238, s. 279.

${ }^{133}$ АВАК, т. 13, № 38, s. 115.

${ }^{134}$ АСДСЗР, т. 8, № 66, s. 290.

${ }^{135}$ АВАК, т. 13, № 38, s. 115.

${ }^{136}$ Istorijos archyvas, t. 1: XVI amžius Lietuvos inventoriai, sudare Konstantinas JABLONSKIS, Kaunas 1934, nr 6, s. 55.

${ }^{137}$ Instrukcijos feodalinių valdų, nr 1, s. 3; nr 11b, s. 34; ABAK, т. 33, № 191, s. 286: wspomniana droga wielka Subocz-Wilno była zapewne odgałęzieniem, które prowadziło do drogi wielkiej.

${ }^{138}$ АСДСЗР, т. 8, № 66, s. 290.

${ }^{139}$ LMMPA, t. 4: Alytus, suderė Antanas Tyla, Vilnius 2006, nr 1, s. 78.

${ }^{140}$ Ibid., t. 7: Merkinés miesto aktai (1598-1627), suderè Algirdas Baliulis, Vilnius 2010, nr 418, s. 601 .

${ }^{141}$ АВАК, т. 11, № 20, s. 46-47; т. 8, № 5, s. 14.

${ }^{142}$ Lietuvos Metrika. Knyga Nr. 20, nr 91, s. 153; ABAK, т. 20, № 278, s. 367.

${ }^{143}$ ABAK, т. 11, № 20, s. 47. 
„до дороги, которая идеть с того села Кудышевич до места Виленского” $(1593 \text { r. })^{144}$.

Do miast prowadziły nie tylko drogi wiejskie, biegnące z siół, lecz także z dworów szlacheckich: „przy rzece Wilii i przy drodze, która idzie od dworu Sołtany z Szeszkini” (1499 r.) $)^{145}$; „черезъ дорогу, которая зъ Вильна идетъ до двора пана Влосковского” (1593 r. $)^{146}$; „черезъ дорогу, которая зъ Вильна идеть до двора пана Влашкова” (1594 r.) ${ }^{147}$. O drogach wiodących do posiadłości szlacheckich świadczą ich nazwy, które najczęściej pochodzą od nazwisk właścicieli dóbr ${ }^{148}$. Układ traktów zależał od tego, jak mieszkańcy funkcjonowali jako wspólnota. Miasto przyciągało kupców, rzemieślników, przedstawicieli szlachty. A w zależności od warunków życia i działalności gospodarczej na danym obszarze układała się też tam sieć komunikacyjna ${ }^{149}$.

Miasto Wilno z odległymi ośrodkami łączyły drogi wielkie i pospolite. Jedne i drugie łączyły ze stołecznym ośrodkiem również miasteczka i wsie znajdujące się na szlaku. Przykład Wilna pokazuje jednak, że część mniejszych miejscowości (a także szlacheckich dworów) położona nieopodal stolicy miała z nią bezpośrednie połączenie, często przez oddzielną drogę.

Osobno należy wymienić kategorię dróg, które powstały w wyniku procesu tworzenia się struktury państwa i weszły do ogólnego systemu dróg WKL. Drogi wielkie generalnie łączyły duże miasta położone od siebie w dużych odległościach. Źródła podają, że niektóre z nich nosiły imię władcy, ewentualnie znajdziemy tam stwierdzenia potwierdzające, że były to drogi należące do monarchy, znajdujące się pod jego szczególną opieką. Na przykład w dokumencie z 1467 r. czytamy: „По Оленецъ а по великою дорогу по Витовътову” ${ }^{150}$, a w akcie z 1484 r.: „по великою дорогу по Витовтову, почонши отъ Марковского перевозу ажъ у каменный мостъ у Витовтовъ" 151 . Podobne świadectwo odnajdujemy w dokumencie z 1536 r. opisującym granice nieużytków Bielska rozciągających się w kierunku Goniądza: „тыхъ околовъ, Витолтова дорога была до того двора, што на Войдиловце ловища была"152. Zapewne wymieniono tu należące do władcy

${ }^{144}$ Ibid., т. 31: Акты о титовских татарах, Вильна 1906, № 95, s. 143; № 303, s. 500; т. 11, № 23 , s. 64 ; № 26 , s. 73 .

${ }^{145}$ Vilniaus žemutinè pilis XIV a. - XIX a. pradžioje. 2002-2004 m. istorinių šaltiniu paieškos, sudarè Raimonda RAGAUSKIENE், Vilnius 2006, s. 69.

${ }^{146}$ ABAK, T. 11, № 20, s. 50.

${ }^{147}$ Ibid., т. 8, № 5, s. 13.

${ }^{148}$ АСДСЗР, т. 2, Вильна, 1867, № 88, s. 152; Istorijos archyvas, t. 1, nr 18, s. 162 (1565 r.): pismo z 1565 r. dotyczące podziału ziem dworów w Płonianach (lit. Plonènai) i Linkowie (lit. Linkuva), wzmiankowana droga do pasieki.

149 Stanisław Alexandrowicz, Miasteczka Białorusi i Litwy jako ośrodki handlu w XVI w. i w I połowie XVII wieku, [in:] idem, Studia z dziejów miasteczek, s. 151-234.

${ }^{150}$ Lietuvos Metrika. Knyga Nr. 25 (1387-1546). Užrašymų knyga 25, parengė Darius AntanAvičıus, Algirdas Baliulis, Vilnius 1998, nr 215, s. 268.

${ }^{151}$ АЮЗР, т. 1, № 31, с. 21; Lietuvos Metrika. Knyga Nr. 25, nr 214, s. 267; nr 215, s. 268.

152 АСДСЗР, т. 1, Вильна 1867, № 17, s. 16. 
tereny służące do polowania, do których wiodły drogi. Wspomniane w powyższych fragmentach „drogi Witolda” miały ważne znaczenie w kontekście zarządzania państwem przez wielkiego księcia, albowiem stanowiły trasy jego podróży wewnątrz WKL ${ }^{153}$. Znaczenie tych traktów spowodowało, że zasłużyły one na miano „drogi władcy”. Pamięć o ważnych traktach z czasów Witolda przetrwała bardzo długo, co wskazuje też na długi czas ich istnienia. „Gościniec Witolda” („гостинца Витолтова") został wspomniany w opisie granic WKL i Polski na Podlasiu w 1546 r. ${ }^{154} \mathrm{~W}$ rozkazie króla Zygmunta III Wazy z roku 1615 wskazano, że należy uporządkować drogę Słuck-Mińsk, aby była ona taka jak za czasów Witolda ${ }^{155}$. Tak długa pamięć o „czasach Witoldowych” pokazuje, jak ważne procesy kształtowania się struktury terytorialnej WKL zachodziły w okresie jego panowania, kiedy nawet rozwój systemu dróg w państwie wiązano z imieniem tego władcy.

W źródłach zachowała się niejedna wzmianka dotycząca „dróg władcy”. W XVI w. spotykamy informacje o „drogach królewskich”. W 1517 r. w opisie ustalania przez komisarzy granic posiadłości w powiecie pińskim wspomina się: „Къ дорогу великому къ дорозе звечной королевской" ${ }^{156}$. W dokumentach delimitacyjnych WKL i Inflant z 1545 r. także mówi się: „per regiam viam ad lacum Nedrowitz” ${ }^{157}$; „ad viam regiam duo lapides” (w okolicach Rakiszek (lit. Rokiškis)) ${ }^{158}$. Wszystko to świadczy o wpływie władcy na tworzenie się struktury dróg w państwie litewskim. Zdaniem Bożeny Wyrozumskiej w średniowieczu i na progu epoki nowożytnej władca dysponował regalem drogowym, ponieważ było to niezbędne dla centralizacji państwa, ale także ważne ze względów militarnych ${ }^{159}$. W zaleceniach władcy z 1561 r. wymienione zostały drogi w WKL, którymi żołnierze Korony Polskiej powinni się przedostać do Inflant ${ }^{160}$. Oznacza to, że nimi z łatwością mogło się przemieszczać wojsko, przewożono broń i zapasy wojskowe. Do tego niezbędne było doglądanie dróg, a tego typu prace na skalę całego państwa mógł podjąć tylko władca. Wszystko to świadczy o tym, że istniały trakty o znaczeniu strategicznym. W wielu przypadkach ich znaczenie sięgało jeszcze głębokiego średniowiecza.

${ }^{153}$ АВАК, т. 24: Акты о боярах, Вильна 1897, № 139, s. 218.

${ }^{154}$ АСДСЗР, т. 1, № 31, s. 81; АВАК, т. 25: Инвентари и разграничительные акть, Вильна 1898, s. 296-297; Pergamentų katalogas, sudarė Rimantas JASAs, Vilnius 1980, nr 315, s. 126. Podobnie „drogi władcy” istniały w państwie moskiewskim. Zob. Сергей Ф. Платонов, Къ истории городовъ и путей на южной окраине Московскаго государства въ XVI веке, Журналь Министерства Народнаго Просвещения, ч. 316, Москва 1898, s. 88.

${ }^{155}$ А. Доўнар, op.cit., s. 64. W źródłach z XVI w. zostały wspomniane „wieczne” drogi: „дорогу звечистую, которая идетъ з Сланима до Рожаное” (АВАК, т. 22, № 538, s. 286).

${ }^{156}$ Александр Грушевский, Пинское полесье, Киевъ 1901 (źródła podane w załączniku), № 22, s. 27; АСДСЗР, т. 1, № 17, s. 15.

157 T. Čelkis, D. AntanaviČIUs, op.cit., s. 171.

${ }^{158}$ Ibid., s. 174; РИБ, т. 30, № 882, s. 888; АСДСЗР, т. 1, № 31, s. 109.

159 Bożena Wyrozumska, Drogi w ziemi krakowskiej do końca XVI wieku, Wrocław-Warszawa-Kraków-Gdańsk 1977, s. 14-18.

${ }^{160}$ Lietuvos Metrika. Knyga Nr. 564 (1553-1567). Viešuju reikalu knyga 7, parengè Algirdas BALIULIS, Vilnius 1996, nr 30, s. 51. 
Podsumowując rozważania, można wyodrębnić następujące kategorie dróg w WKL (w zależności od ich znaczenia), które stanowiły system dróg państwowych. Najważniejszymi były wielkie drogi państwowe, nazywane drogami królewskimi (drogami władców), które powstały w trakcie kształtowania się struktury państwa; dalej były drogi wielkie i gościńce łączące duże miasta; potem drogi o charakterze lokalnym, prowadzące do wielkich traktów, i wreszcie niewielkie drogi, które łączyły dwory i wsie między sobą bądź bezpośrednio z większymi miastami. Można zauważyć, że podział dróg w WKL ma wiele wspólnych cech ze strukturą dróg jeszcze z czasów Cesarstwa Rzymskiego, gdzie także były drogi: państwowe, wielkie, o znaczeniu lokalnym oraz prywatne ${ }^{161}$.

\section{WNIOSKI}

1. Źródła sporządzone w języku ruskim, polskim, łacińskim zawierają definicje pojęcia „droga”, które służyły do określenia dróg o różnym charakterze. Drogi w miejscowościach oraz ścieżki nazywane są: „дорожка”, „стешка”. Większe drogi w miejscowościach określane są jako: „дорога”, „droga”, „viae” i „tractus”. Czasami pojęcia te zastępowano specjalnym określeniem „droga wielka”, a także gościńce: „гостинца”, „goscienca”, „великая дорога”, „доброволна дорога”, „droga gosćiniec wielka”, „via publica”. Stosowane w odniesieniu do drogi określenie „путь” oznaczało nie tylko samą drogę, lecz także osiadłą miejscowość. Taką definicję miejscowości często się spotyka na ziemiach ruskich, szczególnie w okolicach Smoleńska.

2. Główne drogi, zwane drogami wielkimi i drogami pospolitymi, łączyły ważne ośrodki administracyjne i handlowe, ale zdarzało się, że w źródłach występują „drogi wielkie” jako trakty łączące miejscowości leżące w niewielkiej odległości (nawet niespełna $20 \mathrm{~km}$ ). Nie były to odrębne drogi wielkie, lecz w rzeczywistości stanowiły jedynie odcinki większych dróg.

3. Na układ dróg wpływały otoczenie geograficzne i rozwój miejscowości. Drogi omijały bagna, lasy i jeziora. W miejscach trudno przejezdnych wykorzystywano urządzenia inżynieryjne, które ułatwiały transport. Przez rzeki budowano mosty, w pozostałych przypadkach korzystano z promów lub z brodów. Przez bagna i moczary budowano gaci. Były to odcinki dróg wyłożone gałęziami drzew oraz bierwionami. Takie fragmenty traktów są nazywane niekiedy w źródłach „mostami”. Rozciągały się one czasami na duże odległości, liczące kilka, a nawet kilkanaście kilometrów.

4. W WKL występowały też klasyczne groble, które stanowiły wały ziemne budowane na grząskich odcinkach dróg. Przekrój takiej grobli przedstawia rycina z połowy XVII w. ukazująca plan dróg okolic Bowska w Księstwie Kurlandii i Semigalii. Grobla ta składała się z pięciu warstw, które zawierały w sobie drewno i faszynę, ziemię, a w zewnętrznej najwyższej warstwie gruby żwir.

${ }^{161}$ Zob. Adriana Rosset, Starożytne drogi i mosty, Warszawa 1970, s. 85-86. 
5. W celu usprawnienia komunikacji na kluczowych traktach, wiodących do ważnych ośrodków handlowych, stawiano znaki drogowe, które wskazywały kierunek podróży, a czasami też podawały odległość do danego miasta. W roli znaków mogły występować krzyże, a także murowane słupy.

6. Na przykładzie Wilna i sieci drogowej związanej z tym miastem widać pewne charakterystyczne cechy struktury komunikacyjnej WKL. Wilno z bardziej odległymi ośrodkami łączyły gościńce i drogi wielkie. Z kolei mniejsze miejscowości, jeśli nie leżały na tych głównych szlakach, były połączone z gościńcami i wielkimi traktami przez mniejsze drogi. Jednocześnie mieszkańcy okolic Wilna - z siół i dworów szlacheckich - byli połączeni z tym miastem przez oddzielne i bezpośrednie drogi.

7. Niektóre drogi wielkie określano mianem „dróg królewskich” lub imionami konkretnych władców („drogi Witolda”). Nazewnictwo to podkreśla znaczenie tych dróg, a jednocześnie zwraca uwagę na rolę wielkich książąt litewskich w rozwoju struktury dróg państwowych.

8. Z punktu widzenia znaczenia ekonomicznego czy militarnego drogi w WKL można podzielić na: wielkie (główne) drogi władcy; inne drogi wielkie i gościńce łączące większe miasta; drogi o znaczeniu lokalnym; wreszcie niewielkie drogi, łączące wsie i dwory między sobą, a także z większymi ośrodkami miejskimi.

\section{DER ZUSTAND DER LANDSTRASSEN UND DIE VERKEHRSWEGESTRUKTUR IM GROSSFÜRSTENTUM LITAUEN VOM ENDE DES 15. BIS ZUM 17. JAHRHUNDERT}

\section{Zusammenfassung}

Schlüsselbegriffe: Verkehrsnetz, historische Geographie, frühneuzeitliches Litauen, Kommunikation über Land

Im Artikel werden die Struktur und der Zustand der Landstraßen im Großfürstentum Litauen vom Ende des 15. bis zum 17. Jahrhundert analysiert. Er bespricht die in den Quellen anzutreffenden Bezeichnungen für unterschiedliche Arten von Straßen und untersucht das Problem ihrer Qualität. Zudem werden die im Großfürstentum Litauen angewandten Verbesserungen zur Erleichterung von Transport und Kommunikation innerhalb des Landes beschrieben. Große Aufmerksamkeit gilt der Wegestruktur im Großfürstentum Litauen, die am Beispiel Wilnas als dem wichtigsten politischen und wirtschaftlichen Zentrum analysiert wird. 
[395] Stan dróg lądowych i struktura systemu połączeń w Wielkim Księstwie Litewskim...

THE CONDITION OF ROADS AND THE STRUCTURE OF THE SYSTEM OF COMMUNICATION IN THE GRAND DUCHY OF LITHUANIA

\section{Summary}

Key words: networks of roads, historical geography, Lithuania in the Early Modern period, land transport

The article analyses the structure and condition of land roads in the Grand Duchy of Lithuania from the end of the $15^{\text {th }}$ to the $17^{\text {th }}$ centuries. Various definitions of roads are discussed here. The author also addresses the problem of the quality of roads and improvements facilitating transport and communication in the Grand Duchy of Lithuania. The author focuses on the structure of roads in the Grand Duchy, which was analysed by looking at the example of Vilnius - the main political and economic centre in the Grand Duchy of Lithuania. 